\title{
Biochemical Characterization of a Thiol-Activated, Oxidation Stable Keratinase from Bacillus pumilus KS12
}

\author{
Rinky Rajput, Richa Sharma, and Rani Gupta \\ Department of Microbiology, University of Delhi, South Campus, New Delhi 110021, India \\ Correspondence should be addressed to Rani Gupta, ranigupta15@rediffmail.com \\ Received 23 January 2010; Accepted 16 June 2010 \\ Academic Editor: Roberto Fernandez Lafuente
}

Copyright () 2010 Rinky Rajput et al. This is an open access article distributed under the Creative Commons Attribution License, which permits unrestricted use, distribution, and reproduction in any medium, provided the original work is properly cited.

\begin{abstract}
An extracellular keratinase from Bacillus pumilus KS12 was purified by DEAE ion exchange chromatography. It was a $45 \mathrm{kDa}$ monomer as determined by SDS PAGE analysis. It was found to be an alkaline, serine protease with $\mathrm{pH}$ and temperature optima of 10 and $60^{\circ} \mathrm{C}$, respectively. It was thiol activated with two- and eight-fold enhancement in presence of $10 \mathrm{mM}$ DTT and $\beta$ mercaptoethanol, respectively. In addition, its activity was stimulated in the presence of various surfactants, detergents, and oxidizing agents where a nearly 2- to 3-fold enhancement was observed in presence of $\mathrm{H}_{2} \mathrm{O}_{2}$ and $\mathrm{NaHClO}_{3}$. It hydrolyzed broad range of complex substrates including feather keratin, haemoglobin, fibrin, casein, and $\alpha$-keratin. Analysis of amidolytic activity revealed that it efficiently cleaved phenylalanine $\rightarrow$ leucine $\rightarrow$ alanine- $p$-nitroanilides. It also cleaved insulin B chain between $\mathrm{Val}^{2}-\mathrm{Asn}^{3}$, Leu ${ }^{6}-\mathrm{Cys}^{7}$ and $\mathrm{His}^{10}-\mathrm{Leu}^{11}$ residues.
\end{abstract}

\section{Introduction}

Keratinases [3.4.21/24/99.11] are produced by a large number of bacteria, actinomycetes, and fungi, with unique ability to act on "hard to degrade" keratins which are found in bulk in the environment in the form of feather, nail, hair, hoof and so forth [1,2]. By virtue of this ability, they are being exploited in various biotechnological applications in the sectors of ecologically friendly leather processing, nutritional improvement of waste feather for livestock feed, and production of protein hydrolysates from keratinous waste materials [2, 3]. In addition to this, they are also considered as desirable detergent additives which could replace the traditional proteases for removal of keratinous soils that are often encountered in laundry, such as collar washings to remove scurf and for eliminating horny epithelial cells adhered to textile fibers $[1,2]$. To get significant importance as detergent additives, they should be robust in terms of their compatibility towards oxidizing agents, detergents, and surfactants and stability under high temperature and alkaline $\mathrm{pH}[2,4]$. However, oxidation stability is not a commonly encountered characteristic among well known detergent compatible proteases and is generally induced in them by site-directed mutagenesis and protein engineering $[5,6]$. Thus, keratinases with robust characteristics like oxidation stability, alkaline stability, detergent compatibility, and temperature tolerance can fetch a good market among detergent proteases. Here we report the detailed characterization of a detergent compatible and oxidation stable keratinase from Bacillus pumilus KS 12 .

\section{Materials and Method}

2.1. Bacterial Strain. A feather degrading strain of Bacillus pumilus KS12 isolated from garden soil of South Campus, New Delhi was used for the present study. Stock cultures of the strain were maintained in 50\% (v/v) glycerol and stored at $-80^{\circ} \mathrm{C}$. The complete $16 \mathrm{~S}$ rDNA sequence of the present strain has been submitted to the Gen Bank database (Accession no. EU874879).

2.2. Source of Keratin Substrate. Chicken feathers for the keratinase production were obtained from local poultry plants. Feathers were washed with distilled water and finally autoclaved at $15 \mathrm{psi}$. The autoclaved feathers were dried in an oven. 
TABLE 1: Purification scheme of keratinase.

\begin{tabular}{lccccc}
\hline Components & Total enzyme activity $(\mathrm{U})$ & Total protein $(\mathrm{mg})$ & Specific activity $(\mathrm{U} / \mathrm{mg})$ & Recovery $(\%)$ & Purification fold \\
\hline Lyophilized Culture broth & 2170.00 & 12.00 & 180.83 & 100.00 & 1.00 \\
DEAE-Sepharose & 716.00 & 1.80 & 397.77 & 32.99 & 2.19 \\
\hline
\end{tabular}

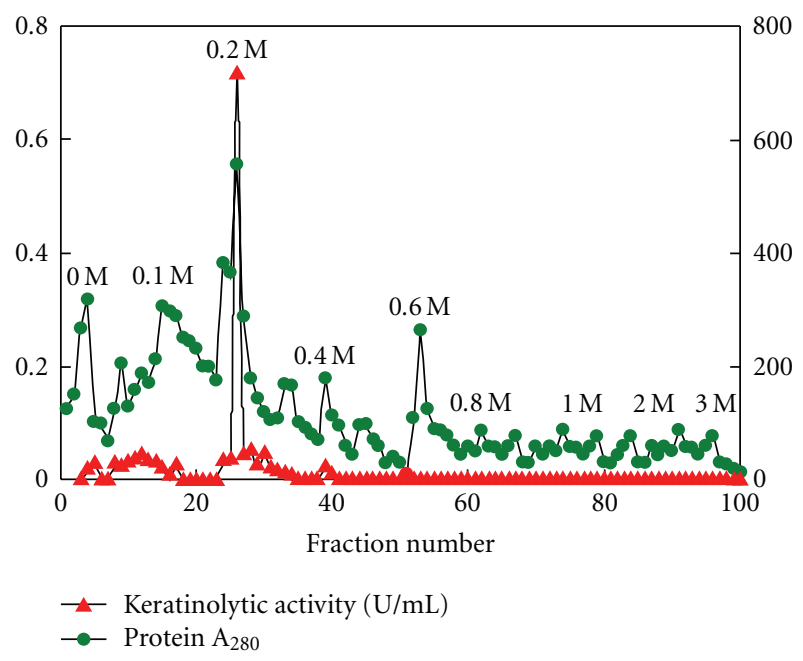

FIGURE 1: Elution profile of keratinase on DEAE-Sepharose column.

2.3. Keratinase Production. Feather soy flour medium containing following constituents $(\mathrm{g} / \mathrm{L})$ : chicken feather 5.0, glucose 5.0, soy flour 5.0, $\mathrm{KH}_{2} \mathrm{PO}_{4} 1.0, \mathrm{~K}_{2} \mathrm{HPO}_{4} 3.0$, and $\mathrm{MgCl}_{2} 5 \mathrm{mM}$, ( $\mathrm{pH} 7.0$ ) was used for keratinase production. Production was carried out in $250 \mathrm{~mL}$ Erlenmeyer flask containing $50 \mathrm{~mL}$ medium for $24 \mathrm{~h}$ at $37^{\circ} \mathrm{C}, 200 \mathrm{rpm}$ in an incubator shaker (New Brunswick Scientific, Edison NJ, USA).

2.4. Keratinase Activity and Protein Estimation. The keratinase activity was determined as described by Dozie et al. [7]. The assay mixture containing $1 \mathrm{~mL}$ of appropriately diluted enzyme, $4 \mathrm{~mL}$ glycine- $\mathrm{NaOH}$ buffer ( $50 \mathrm{mM}$, pH9.0), and $20 \mathrm{mg}$ of chicken feather was incubated at $70^{\circ} \mathrm{C}$ for $1 \mathrm{~h}$. The reaction was terminated by adding $4 \mathrm{~mL}$ of $5 \%(\mathrm{w} / \mathrm{v})$ trichloroacetic acid. Insoluble residues were removed by filtration through glass wool, and the filtrate was centrifuged at $5000 \times \mathrm{g}$ for $10 \mathrm{~min}$.

Appropriate controls were also set up. Proteolytic products in the supernatant were determined by absorbance at $280 \mathrm{~nm}$ against controls. An increase in absorbance of 0.01 was considered as $1 \mathrm{U}$ enzyme activity. The protein content was estimated by the method of Lowry [8] using BSA as standard in the concentration range $100-1000 \mu \mathrm{g} / \mathrm{mL}$

2.5. Purification of Keratinase. One gram of the lyophilized enzyme was dissolved in $5 \mathrm{~mL}$ of $10 \mathrm{mM}$ Tris- $\mathrm{HCl}$ buffer ( $\mathrm{pH} 8$ ) and loaded on DEAE-Sepharose column (Pharmacia Biotechnology Upsala, Sweden) equilibrated with $10 \mathrm{mM}$ Tris- $\mathrm{HCl}$ buffer (pH8). The column was washed with the

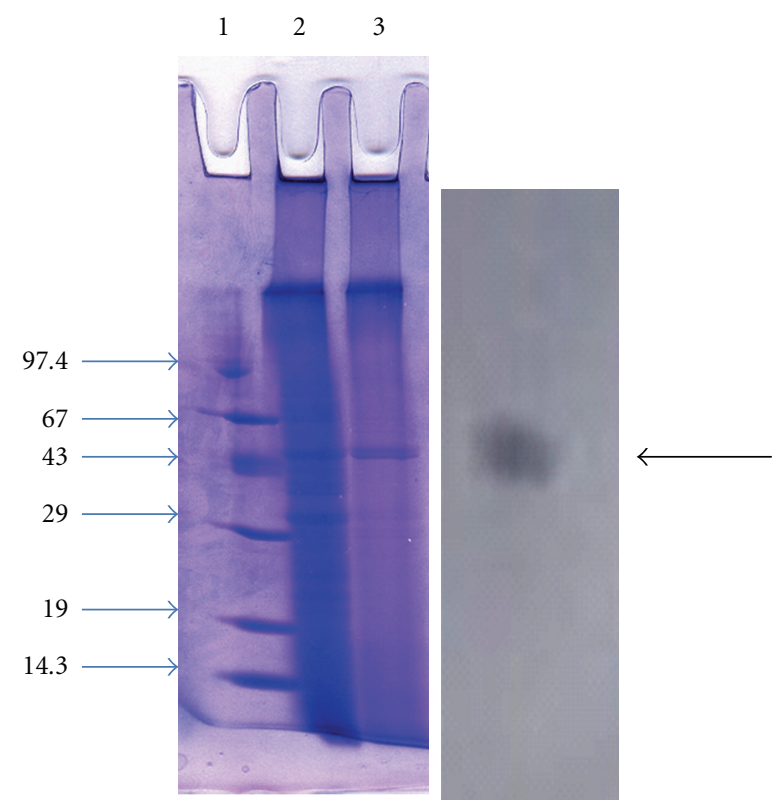

(a)

(b)

FIGURE 2: SDS-PAGE and zymogram analysis of purified keratinase (a) SDS PAGE, Lane 1: Protein molecular mass marker, Lane 2: Culture supernatant, Lane 3: Purified fraction eluted from DEAE Sepharose column (b) Zymogram.

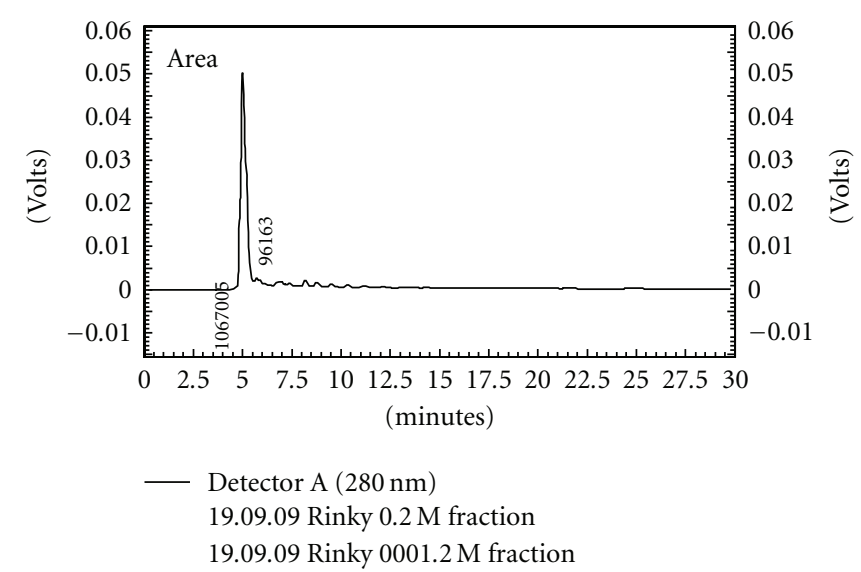

FIGURE 3: HPLC profile of purified keratinase.

same buffer, and $15 \mathrm{~mL}$ fraction was collected at a flow rate of $1 \mathrm{~mL} / \mathrm{min}$. Bound protein was eluted in a linear salt gradient $(0.1 \mathrm{M}-3 \mathrm{M} \mathrm{NaCl})$. Protein elution was monitored at $280 \mathrm{~nm}$, and keratinolytic activity and protein were determined as described earlier. 
TABLE 2: Effect of inhibitors on activity of keratinase.

\begin{tabular}{|c|c|c|c|c|c|}
\hline \multirow{2}{*}{ S. no. } & \multirow{2}{*}{ Concentration (mM) } & \multicolumn{4}{|c|}{ Residual activity (\%) } \\
\hline & & PMSF & EDTA & DTT & $\beta$-mercaptoethanol \\
\hline (1) & 1 & 5.00 & 74.00 & 120.00 & 240.00 \\
\hline (2) & 5 & 0.00 & 70.00 & 158.00 & 609.00 \\
\hline (3) & 10 & 0.00 & 70.00 & 203.00 & 876.00 \\
\hline
\end{tabular}

Control without inhibitors was taken as $100 \%$ activity corresponded to $720 \mathrm{U} / \mathrm{mL}$ on feather keratin as substrate.

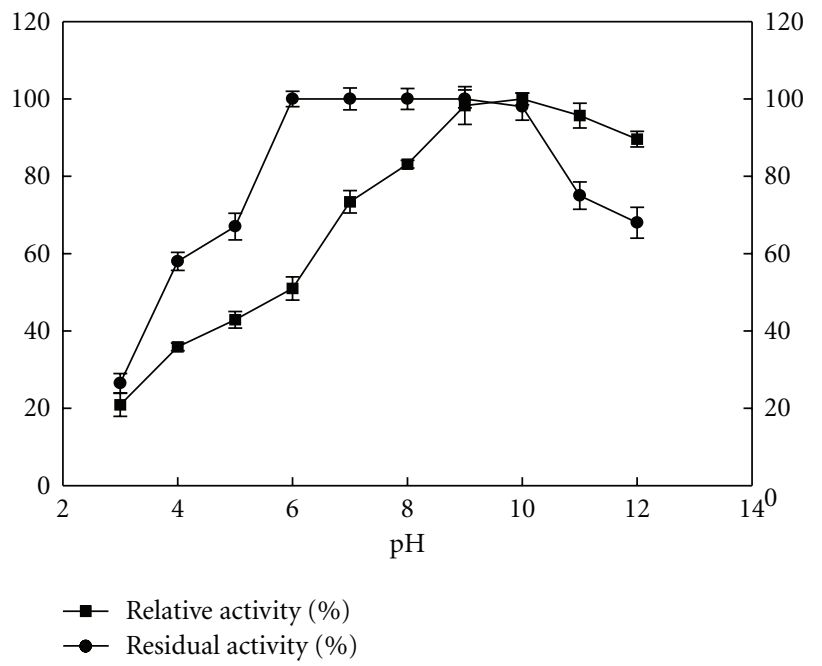

FIGURE 4: Effect of pH on activity and stability of keratinase.100\% activity corresponded to $720 \mathrm{U} / \mathrm{mL}$ on feather keratin as substrate.

2.6. SDS-PAGE and HPLC Analysis. Sodium dodecyl sulphate-polyacrylamide gel electrophoresis was carried out using the method of Laemmli [9] to check the purity of purified fraction, and its purity was confirmed by HPLC using C18column (Shimadzu, Japan) and acetonitrile: water $(90: 10)$ as mobile phase with flow rate of $0.5 \mathrm{ml} / \mathrm{min}$. The protein was detected at $\mathrm{A}_{280}$ using $\mathrm{UV}$ detector.

2.7. Zymogram. The activity staining of purified keratinase was performed by reactivating 10\% SDS-PAGE. After electrophoresis, the gel was soaked for $20 \mathrm{~min}$ in $2.5 \%(\mathrm{v} / \mathrm{v})$ Triton X-100 with constant shaking to remove SDS. The gel was washed thrice with glycine- $\mathrm{NaOH}$ buffer $(100 \mathrm{mM}, \mathrm{pH}$ $10.0)$ to remove Triton $X-100$. The gel was overlaid onto a $1 \%$ casein agar plate prepared in glycine- $\mathrm{NaOH}$ buffer $(100 \mathrm{mM}$, $\mathrm{pH}$ 10.0). Enzyme activity was visualized by incubating the gel for $4 \mathrm{~h}$ at $50^{\circ} \mathrm{C}$. The reaction was stopped by flooding with $5 \%(\mathrm{w} / \mathrm{v})$ TCA. The band of purified keratinase appeared as clear zone against a white background.

\subsection{Biochemical Properties of Keratinase}

2.8.1. Effect of $p H$ and Temperature on the Activity and Stability of Keratinase. The effect of $\mathrm{pH}$ was studied by carrying out the keratinase assay in the $\mathrm{pH}$ range of 3.0-12.0 using 50 mM buffers: $\mathrm{pH}$ 3.0-6.0 (citrate phosphate buffer),

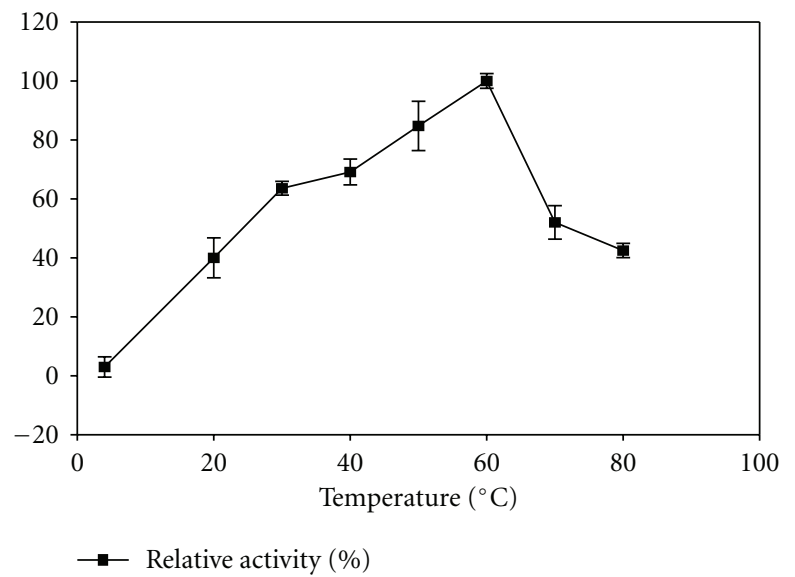

(a)

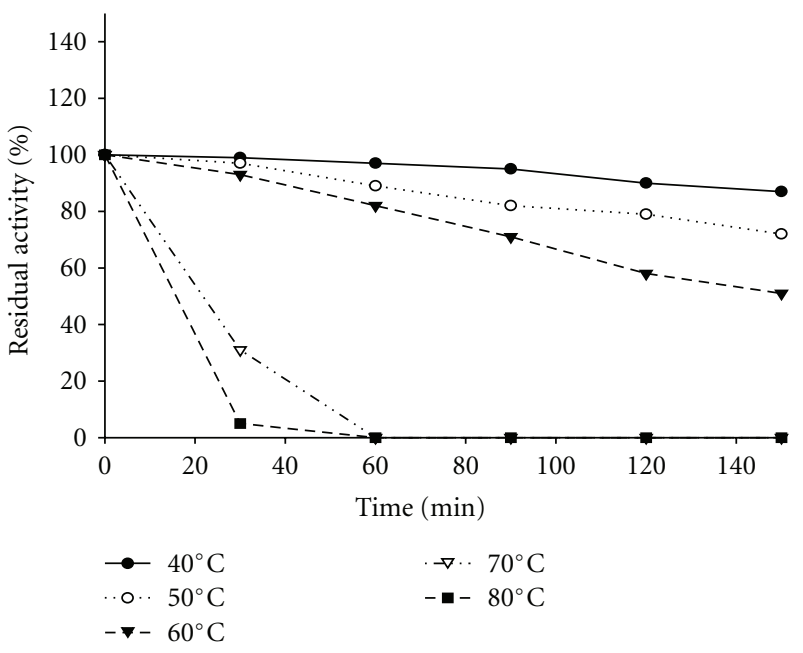

(b)

FIGURE 5: Effect of temperature on the activity of keratinase. 100\% activity corresponded to $720 \mathrm{U} / \mathrm{ml}$ on feather keratin as substrate.

pH 7.0-8.0 (sodium phosphate buffer), pH 9.0-10.0 (glycine$\mathrm{NaOH}$ buffer), $\mathrm{pH} 11.0$ (phosphate hydroxide buffer), and pH 12.0 (hydroxide-chloride buffer). Similarly, the effect of temperature on keratinase activity was determined by incubating the enzyme at temperatures ranging from $4-80^{\circ} \mathrm{C}$ at $\mathrm{pH} 10$. Activity was expressed as percentage relative activity with respect to maximum activity, which was considered as $100 \%$

The $\mathrm{pH}$ stability was determined by preincubating the purified keratinase in buffers of varying $\mathrm{pH}(3.0-12.0)$ for $2 \mathrm{~h}$ 


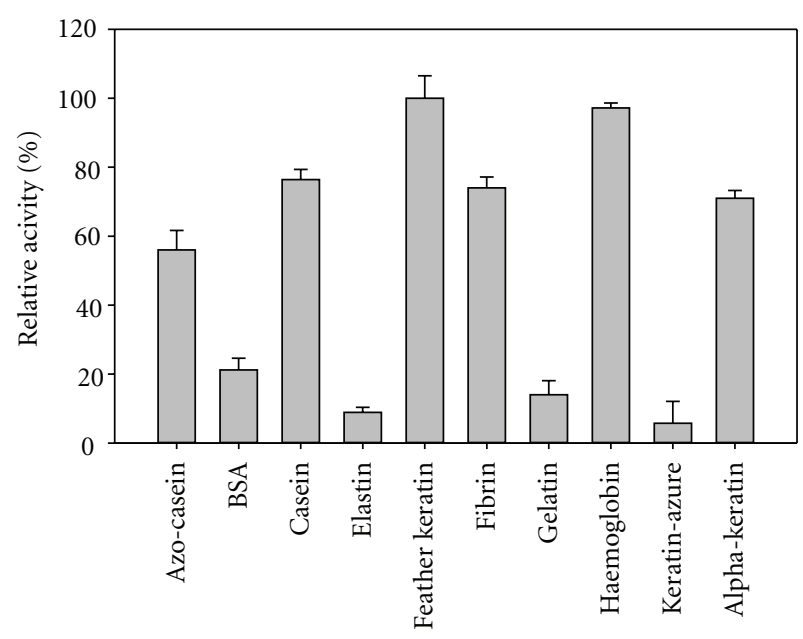

FIGURE 6: Substrate specificity of keratinase on complex substrates.

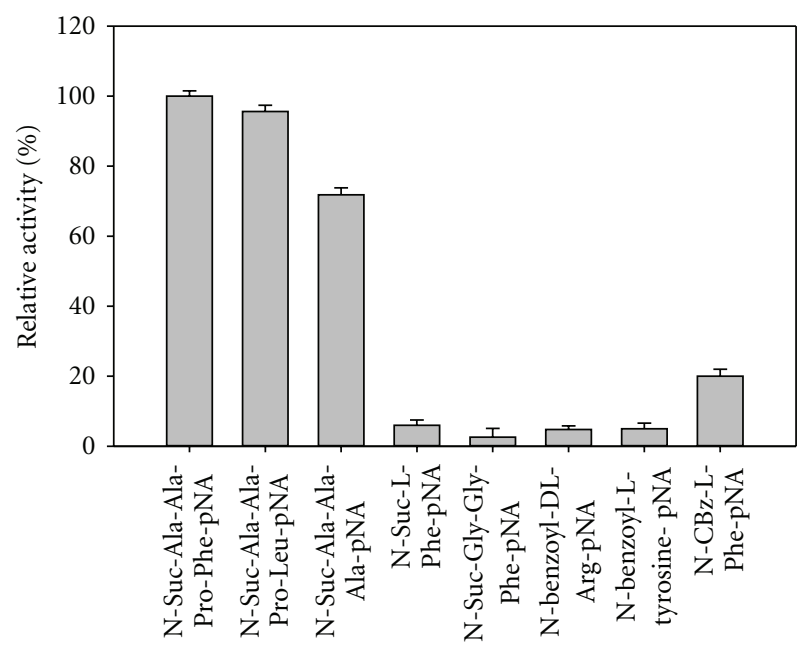

FIGURE 7: Amidolytic activity keratinase on $p$-nitroanilides.

at room temperature, and thereafter the residual activity was determined at $\mathrm{pH} 10.0$ and $60^{\circ} \mathrm{C}$. Similarly, the temperature stability was determined by incubating the enzyme samples at various temperatures ranging from $40-80^{\circ} \mathrm{C}$ for different time intervals up to $2(1 / 2) \mathrm{h}$.

2.8.2. Effect of Inhibitors and Metal Ions. The effect of various inhibitors namely PMSF, 1,10-phenanthroline, EDTA, Nbromosuccinmide, iodoacetamide, and $\beta$-mercaptoethanol, DTT (Sigma-Aldrich USA; ICN chemicals, USA) on keratinase activity was carried out by incubating the enzyme with inhibitors at a final concentration of $1 \mathrm{mM}$ at room temperature for $5 \mathrm{~min}$. Similarly, the effect of metal ions was studied by pre-incubating the enzyme with metal ions namely $\mathrm{Ba}^{2+}, \mathrm{Ca}^{2+}, \mathrm{Cd}^{2+}, \mathrm{Cr}^{3+}, \mathrm{Cu}^{2+}, \mathrm{Hg}^{2+}, \mathrm{Mg}^{2+}, \mathrm{Mn}^{2+}$, $\mathrm{Ni}^{2+}$ and $\mathrm{Zn}^{2+}$ at a final concentration of $5 \mathrm{mM}$ for $1 \mathrm{~h}$ and then determining the residual activity at $\mathrm{pH} 10.0$ and $60^{\circ} \mathrm{C}$. The activity was expressed as residual percentage activity against the control without inhibitors which was taken as $100 \%$.
2.8.3. Stability in Presence of Surfactants, Detergents, and Oxidizing Agents. The compatibility of keratinase towards various ionic and nonionic surfactants namely saponin, triton X-100, sodium cholate, SDS, tween-80, and detergents was tested by pre-incubating the enzyme with surfactants/detergents at a final concentration of $1 \%(\mathrm{w} / \mathrm{v})$ for $1 \mathrm{~h}$ at room temperature. Also, its stability towards oxidizing agents like hydrogen peroxide $\left(\mathrm{H}_{2} \mathrm{O}_{2}\right)$ and sodium cholate $\left(\mathrm{NaHClO}_{3}\right)$ was checked by incubating enzyme with varying concentrations of oxidizing agents for $1 \mathrm{~h}$ at room temperature. Similar controls were set up using inactivated enzyme. The keratinase activity was determined at $\mathrm{pH} 10.0$ and $60^{\circ} \mathrm{C}$. The activity was expressed as relative activity with respect to control (without any additive) which was taken as $100 \%$.

2.8.4. Substrate Specificity of Keratinase. The substrate specificity of the keratinase was studied by comparing proteolysis of both soluble and insoluble substrates namely azo-casein, BSA, casein, gelatin, haemoglobin, elastin, feather keratin, fibrin, keratin azure, and $\alpha$-keratin (Sigma-Aldrich USA). Twenty mg of each of the substrates was added to $1 \mathrm{~mL}$ of appropriately diluted enzyme in glycine- $\mathrm{NaOH}$ buffer $100 \mathrm{mM}, \mathrm{pH} 10.0$ and incubated at $60^{\circ} \mathrm{C}$ for $1 \mathrm{~h}$. The reaction was stopped by adding $4 \mathrm{~mL}$ of $5 \%(\mathrm{w} / \mathrm{v})$ trichloroacetic acid. The contents were centrifuged after $1 \mathrm{~h}$ at $7441 \mathrm{~g}$ for $10 \mathrm{~min}$. Folin Ciocalteau's reagent $(0.5 \mathrm{~mL})$ was added to $1 \mathrm{~mL}$ of the supematant, and the optical density of the samples was taken at $660 \mathrm{~nm}$ against appropriate substrate and enzyme blanks. One unit of protease was equivalent to the amount of enzyme required to release $1 \mu \mathrm{g}$ of tyrosine $\mathrm{mL}^{-1} \mathrm{~h}^{-1}$ under standard assay conditions.

2.8.5. Amidolytic Activity of Keratinase. The purified keratinase was also examined for its ability to hydrolyze synthetic $p$-nitroanilide substrates namely N-Suc-Ala-Ala-Pro-Phe$p N A, N-A l a-A l a-P r o-L e u-p N A, N-S u c-A l a-A l a-A l a-p N A, N-$ Suc-L-Phe-pNA, N-Suc-Gly-Gly-Phe-pNA, N-Benzoyl-DLArg- $p$ NA, and N-Benzoyl-L-tyrosine-pNA, N-CBz-L-PhepNA (Sigma-Aldrich USA; ICN chemicals, USA). Ten mM stock solutions of the peptides were prepared in DMSO. One $\mathrm{mM}$ of the substrates was added to appropriately diluted enzyme in glycine- $\mathrm{NaOH}$ buffer $(100 \mathrm{mM}, \mathrm{pH} 8)$ and incubated at $60^{\circ} \mathrm{C}$. The reaction mix was incubated at optimum temperature for $10 \mathrm{~min}$. The hydrolyzed product was measured at $405 \mathrm{~nm}$ using a UV-Vis spectrophotometer (UV 1700 Shimadzu, Japan). The molar extinction coefficient for pNA was taken to be $9900 \mathrm{M}^{-1} \mathrm{~cm}^{-1}[10]$.

2.8.6. Determination of Kinetic Constants. The most effectively hydrolyzed substrates, N-Suc-Ala-Ala-Pro-Phe-pNA, N-Ala-Ala-Pro- Leu- $p N A$, and casein were selected for kinetic studies. Varying concentrations of synthetic $p$ nitroanilide substrates namely N-Suc-Ala-Ala-Pro-Phe-pNA and N-Suc-Ala-Ala-Pro-Leu- $p \mathrm{NA}(0.1-1.0 \mathrm{mM})$ and casein $(0.5-10 \mathrm{mg} / \mathrm{mL})$ were assayed with $1 \mathrm{~mL}$ appropriately diluted enzyme at optimum $\mathrm{pH}$ and temperature. 
TABLE 3: Stability of the keratinase in the presence of various surfactants and detergents.

\begin{tabular}{|c|c|c|c|}
\hline \multicolumn{3}{|c|}{ Surfactants/ Detergents $(1 \% \mathrm{w} / \mathrm{v}, \mathrm{v} / \mathrm{v})$} & Relative activity (\%) \\
\hline \multicolumn{3}{|c|}{ Control* $^{*}$} & 100.00 \\
\hline \multicolumn{3}{|c|}{ Saponin } & 191.00 \\
\hline \multicolumn{3}{|c|}{ Sodium cholate } & 187.00 \\
\hline \multicolumn{3}{|c|}{ SDS } & 145.00 \\
\hline \multicolumn{3}{|c|}{ Triton-X } & 202.00 \\
\hline \multicolumn{3}{|c|}{ Tween-80 } & 140.00 \\
\hline \multicolumn{4}{|c|}{ Detergents } \\
\hline \multicolumn{2}{|l|}{ Ariel } & & 183.00 \\
\hline \multicolumn{2}{|c|}{ Henko } & & 185.00 \\
\hline \multicolumn{2}{|c|}{ Fena } & & 180.00 \\
\hline \multicolumn{2}{|c|}{ Nirma } & & 183.00 \\
\hline \multicolumn{2}{|c|}{ Rin } & & 180.00 \\
\hline \multicolumn{2}{|l|}{ Surf } & & 160.00 \\
\hline \multicolumn{2}{|l|}{ Tide } & & 179.00 \\
\hline \multicolumn{2}{|c|}{ Wheel } & & 183.00 \\
\hline \multicolumn{4}{|c|}{$\begin{array}{l}\text { * Control set up with inactivated enzyme was taken as } 100 \% \text { activity } \\
\text { corresponded to } 720 \mathrm{U} / \mathrm{mL} \text { on feather keratin as substrate. }\end{array}$} \\
\hline \multicolumn{4}{|c|}{ TABLE 4: Effect of oxidizing agents on activity of keratinase. } \\
\hline \multirow[t]{2}{*}{ S. no. } & Concentration & \multicolumn{2}{|c|}{ Relative activity (\%) } \\
\hline & $(\%)$ & $\mathrm{H}_{2} \mathrm{O}_{2}$ & $\mathrm{NaHClO}_{3}$ \\
\hline (1) & 1 & 328.08 & 257.0 \\
\hline (2) & 2 & 350.0 & 226.0 \\
\hline (3) & 3 & 363.0 & 226.0 \\
\hline
\end{tabular}

Control set up with inactivated enzyme was taken as $100 \%$.

2.8.7. Hydrolysis of Insulin B Chain and Mass Spectrometry. The substrate specificity of keratinase was also studied by hydrolysis of insulin B-chain (Sigma, cysteine residues oxidized). One hundred $\mu \mathrm{L}$ of insulin B-chain $(1 \mathrm{mg} / \mathrm{mL}$ in $10 \mathrm{mM}$ Tris- $\mathrm{HCl}$ buffer, $\mathrm{pH}$ 9) was mixed with $100 \mu \mathrm{L}$ of purified enzyme. The mixture was then incubated at $60^{\circ} \mathrm{C}$ for $16 \mathrm{~h}$. After $16 \mathrm{~h}$ of incubation, $40 \mu \mathrm{L}$ of $0.1 \%$ (v/v) TFA was added to the reaction mixture to inactivate the enzyme. Hydrolysis of insulin B chain by enzyme was analyzed by liquid chromatography-electron spray mass spectrometry (LC-ESI/MS, GenPro Biotech, India). Cleavage sites were determined using FindPept software of Expasy.

\section{Results}

3.1. Purification of Keratinase. One major keratinase peak was eluted from DEAE-Sepharose column in $0.2 \mathrm{M} \mathrm{NaCl}$ fraction (Figure 1). Keratinase was purified with a purification fold of 2.19 and an overall recovery of $92 \%$ (Table 1).

3.2. SDS-PAGE and HPLC Analysis. The homogeneity of the purified keratinase was revealed by SDS-PAGE, showing a single band at $45 \mathrm{kDa}$ (Figure 2). Purity was also confirmed by HPLC analysis, where a single major peak having retention time of $4.9 \mathrm{~min}$ was obtained on $\mathrm{C} 18$ column using UV detector (Figure 3). In zymogram, a clear zone of casein hydrolysis was observed against a white background coinciding with the protein band on the gel (Figure 3).

3.3. Effects of $p H$ on the Activity and Stability of Keratinase. The enzyme was active in neutral to alkaline $\mathrm{pH}$ range from $\mathrm{pH}$ 7.0-12.0 with maximum activity corresponding to $720 \mathrm{U} / \mathrm{mL}$ at $\mathrm{pH} 10.0$ (Figure 4). It was completely stable in the $\mathrm{pH}$ range of $\mathrm{pH} 6.0-10.0$ with no loss in activity and retained up to $>50 \%$ activity at extreme acidic $(\mathrm{pH} 4.0-5.0)$ and alkaline $\mathrm{pH}(\mathrm{pH} 11.0-12.0)$ after $2 \mathrm{~h}$ of incubation at room temperature.

3.4. Effect of Temperature on the Activity and Stability of Keratinase. The enzyme was active over a wide temperature range from 30 to $60^{\circ} \mathrm{C}$ with maximum activity at $60^{\circ} \mathrm{C}$ (Figure 5). It was stable over temperatures ranging from $40-60^{\circ} \mathrm{C}$ with $97 \%$ residual activity $(699 \mathrm{U} / \mathrm{mL})$ at $40^{\circ} \mathrm{C}$ followed by $89 \%$ activity $(642 \mathrm{U} / \mathrm{mL})$ at $50^{\circ} \mathrm{C}$ while $82 \%$ residual activity $(591 \mathrm{U} / \mathrm{mL})$ at $60^{\circ} \mathrm{C}$ after $1 \mathrm{~h}$ of incubation at respective temperatures. It exhibited a $t_{1 / 2}>2 \mathrm{~h}$ at $60^{\circ} \mathrm{C}$, $t_{1 / 2}$ of $30 \mathrm{~min}$ at $70^{\circ} \mathrm{C}$, and $t_{1 / 2}$ of $20 \mathrm{~min}$ at $80^{\circ} \mathrm{C}$ (Figure 5).

3.5. Effects of Inhibitors and Metal-Ions. Among the various inhibitors PMSF completely inhibited keratinase activity followed by $70 \%$ residual activity corresponded to $505 \mathrm{U} / \mathrm{mL}$ in presence of $10 \mathrm{mM}$ EDTA. It was highly stimulated by the presence of reducing agents like $\beta$-mercaptoethanol and DTT where twofold activation in presence of $10 \mathrm{mM}$ DTT and eightfold enhancement in $10 \mathrm{mM} \beta$-mercaptoethanol were observed (Table 2). It retained more than $80 \%$ activity in the presence of divalent cations like $\mathrm{Ba}^{2+}, \mathrm{Ca}^{2+}, \mathrm{Cd}^{2+}, \mathrm{Cr}^{2+}, \mathrm{Cu}^{2+}$, $\mathrm{Mg}^{2+}, \mathrm{Mn}^{2+}, \mathrm{Ni}^{2+}$, and $\mathrm{Zn}^{2+}$ after $1 \mathrm{~h}$ of incubation at room temperature (data not shown).

3.6. Stability in Presence of Surfactants, Detergent and Oxidation. Surfactants like saponin, triton X-100, sodium cholate, SDS, and tween-80 stimulated the activity of keratinase with a maximum activation of twofold in presence of triton X100 (Table 3). Remarkable was the compatibility of present keratinase towards various commercially available detergents with a stimulation of 1.8 -fold (Table 3 ) and oxidation stability with nearly two-to threefold enhancements in presence of $\mathrm{H}_{2} \mathrm{O}_{2}$ and $\mathrm{NaHClO}_{3}$ (Table 4).

3.7. Substrate Specificity of Keratinase. Keratinase from B. pumilus KS12 hydrolyzed most of soluble and insoluble complex substrates with $100 \%$ relative activity corresponded to $720 \mathrm{U} / \mathrm{mL}$ on feather keratin and $97 \%$ activity corresponding to $699 \mathrm{U} / \mathrm{mL}$ on haemoglobin followed by $>50 \%$ relative activity on casein, fibrin, $\alpha$-keratin, and azo-casein while, BSA, gelatin, and elastin were least hydrolyzed with $<20 \%$ relative activity, respectively (Figure 6). Among synthetic substrates, it hydrolyzed N-Suc-Ala-Ala-Pro-Phe$p \mathrm{NA}>\mathrm{N}$-Ala-Ala-Pro-Leu- $p$ NA $>$ N-Suc-Ala-Ala-Ala- $p$ NA. Kinetic studies revealed a $\mathrm{K}_{\mathrm{m}}$ of $0.25 \mathrm{mg} / \mathrm{mL}, 0.1 \mathrm{mM}$, and $0.25 \mathrm{mM}$ and $V_{\max }$ of $0.75 \mu \mathrm{g} / \mathrm{mL} / \mathrm{min}, 2.0 \mu \mathrm{moles} / \mathrm{mL} / \mathrm{min}$, 


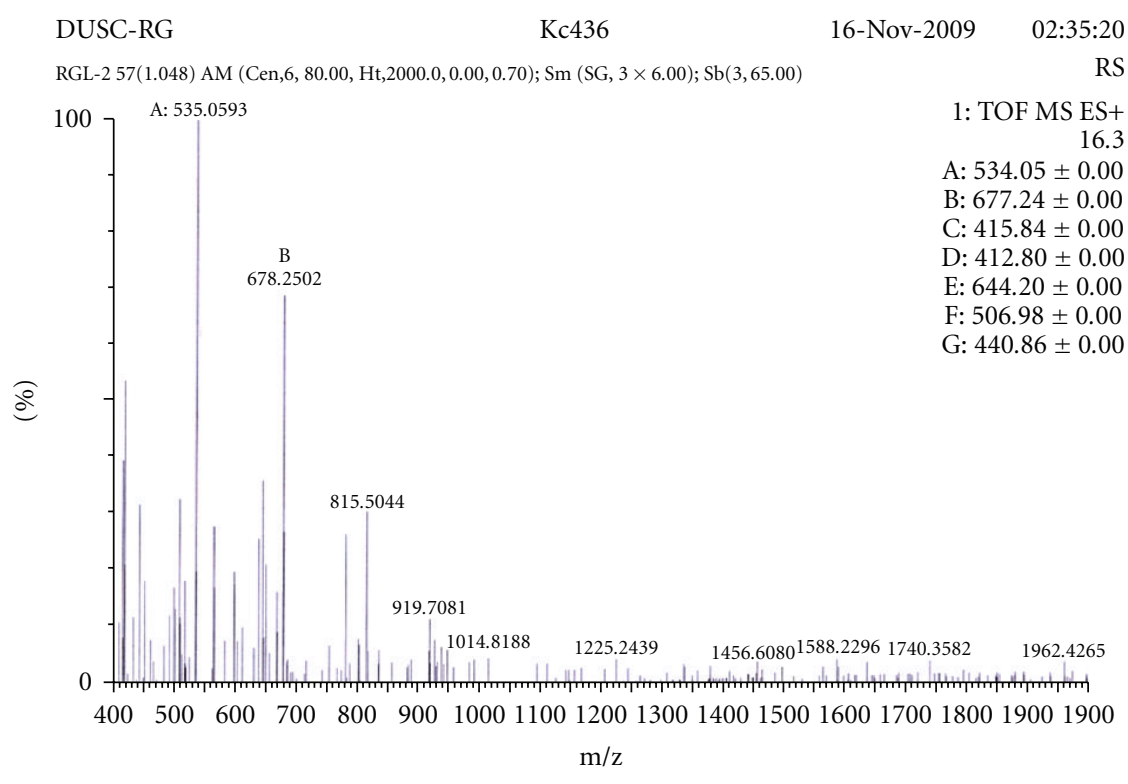

(a)

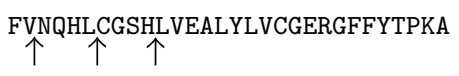

(b)

FIGURE 8: Hydrolysis of insulin B-chains (with oxidized cysteine residues) by purified keratinase. (a) ESI-LC-MS/MS data (b) Sequence of insulin B-chain. Arrows represent cleavage sites.

and $3.0 \mu \mathrm{moles} / \mathrm{mL} / \mathrm{min}$ on casein, N-Suc-Ala-Ala-Pro-Phe$p \mathrm{NA}$, and N-Ala-Ala-Pro-Leu-pNA, respectively (Table 5). LC-ESI/MS analysis of the hydrolyzed insulin B-chain revealed the cleavage sites to be between $\mathrm{Val}^{2}-\mathrm{Asn}^{3}, \mathrm{Leu}^{6}$ Cys $^{7}$, and His ${ }^{10}$-Leu ${ }^{11}$ (Figure 8).

\section{Discussion}

Bacillus pumilus KS12 is a potential feather degrader as it degraded chicken feathers within $24 \mathrm{~h}$ at $37^{\circ} \mathrm{C}, 200$ rpm. Keratinases from Bacillus species and Streptomyces species have been extensively studied, however, till date only Bacillus licheniformis keratinase has been commercially well established [2]. A $45 \mathrm{kDa}$ monomeric keratinase was purified from the fermentation broth of Bacillus pumilus KS12. This is different from the earlier reported keratinases from Bacillus pumilus which are of 34 and $65 \mathrm{kDa}[11,12]$.

Keratinase from Bacillus pumilus KS12 was an alkaline, serine protease with maximal activity at $\mathrm{pH} 10$. This is in accordance with several earlier reports on microbial keratinases showing $\mathrm{pH}$ optima in alkaline range of $\mathrm{pH} 8$ to 11 [2]. However, it was different from the optima of $\mathrm{pH} 9$ and pH8 for keratinase from Bacillus pumilus A1 and Bacillus pumilus CLRI, respectively $[13,14]$. It is assumed that alkaline conditions aid in breaking of disulfide bonds and assists rapid feather degradation. It also had a wide range of $\mathrm{pH}$ stability with more than $90 \%$ relative activity over a range of $\mathrm{pH}$ 6-10.

Keratinases from Bacillus pumilus KS12 had temperature optima at $60^{\circ} \mathrm{C}$. Most keratinases are thermoactive with temperature optima in the range of $50-60^{\circ} \mathrm{C}$ with some exceptions such as Fervidobacterium islandicum AW-1 keratinase which showed high temperature optima of $90^{\circ} \mathrm{C}$ and
TABLE 5: Kinetic parameters of purified keratinase on casein and $p$ NA.

\begin{tabular}{lccc}
\hline Substrates & $\mathrm{K}_{\mathrm{m}}$ & $V_{\max }$ & $\mathrm{K}_{\mathrm{cat}}\left(\mathrm{min}^{-1}\right)$ \\
\hline $\begin{array}{l}\text { Casein } \\
\text { N-Suc-Ala- }\end{array}$ & $0.25 \mathrm{mg} / \mathrm{mL}$ & $0.75 \mu \mathrm{g} / \mathrm{mL} / \mathrm{min}$ & 3.0 \\
$\begin{array}{l}\text { Ala-Pro-Phe- } \\
\text { pNA }\end{array}$ & $0.1 \mathrm{mM}$ & $2.0 \mu \mathrm{moles} / \mathrm{mL} / \mathrm{min}$ & 20.0 \\
$\begin{array}{l}\text { N-Ala-Ala- } \\
\text { Pro-Leu-pNA }\end{array}$ & $0.25 \mathrm{mM}$ & $3.0 \mu \mathrm{moles} / \mathrm{mL} / \mathrm{min}$ & 12.0 \\
& & &
\end{tabular}

$100^{\circ} \mathrm{C}$, respectively [11]. The present keratinase also had high stability more than $80 \%$ over a temperature range of $40-60^{\circ} \mathrm{C}$ with a $t_{1 / 2}>2 \mathrm{~h}$ at $60^{\circ} \mathrm{C}$.

It was inhibited by PMSF thus it is a serine protease. This is in confirmation with most of the reported keratinases [2]. Noteworthy was the fact that it was highly thiol activated as its activity was enhanced by two and eight folds in presence of $10 \mathrm{mM}$ DTT and $\beta$-mercaptoethanol. Thiol activation of keratinases has been reported earlier, and it is a positive attribute for their action on cysteine rich keratin substrates [2].

The present enzyme had broad substrate specificity for both soluble and insoluble complex and synthetic substrates. It effectively hydrolyzed most of complex substrates with maximum activity on feather keratin followed by haemoglobin, casein, fibrin, $\alpha$-keratin, azocasein, and gelatin. Most of the keratinolytic enzymes do have good caseinolytic activity [1]. Hence, K: C (keratinolytic: caseinolytic) ratio is regarded as a parameter for comparing keratinolytic potential of various proteases, and 
a protease with ratio of $>0.5$ is considered as a keratinase [12]. In this perspective, the present enzyme is a potential keratinase with a $\mathrm{K}: \mathrm{C}$ of 1.5 . Besides this, the activity on synthetic substrates and insulin B-chain cleavage also revealed that it preferentially cleaves hydrophobic residues. This again reconfirms its action on insoluble, hydrophobic proteins. By virtue of these properties, it can become a potential catalyst for degradation of insoluble, hard-todegrade proteins including prion plaques.

Overall, the present keratinase is a thermoactive, alkaline, thiol-activated, oxidation stable enzyme with broad range of substrate specificity and thus can find applications in various industries especially in detergent sector for collar washings to remove scurf and in hospital washings to remove blood stains.

Further work can be extended towards development of commercially viable enzyme by immobilization on inert insoluble substrates as reported earlier for keratinase from Bacillus subtilis on calcium alginate beads [15] and recently on polymer assisted nanoparticles from Bacillus subtilis [16] and Bacillus halodurans [3].

\section{Acknowledgments}

The authors thank the financial assistance from University of Delhi and Department of Biotechnology, Ministry of Science and Technology, New Delhi. R. Sharma acknowledges the University Grant Commission for providing her with the JRF fellowship.

\section{References}

[1] R. Gupta and P. Ramnani, "Microbial keratinases and their prospective applications: an overview," Applied Microbiology and Biotechnology, vol. 70, no. 1, pp. 21-33, 2006.

[2] A. Brandelli, D. J. Daroit, and A. Riffel, "Biochemical features of microbial keratinases and their production and applications," Applied Microbiology and Biotechnology, vol. 85, no. 6, pp. 1735-1750, 2010.

[3] P. Prakash, S. K. Jayalakshmi, and K. Sreeramulu, "Production of keratinase by free and immobilized cells of Bacillus halodurans strain PPKS-2: partial characterization and its application in feather degradation and dehairing of the goat skin," Applied Biochemistry and Biotechnology, vol. 160, no. 7, pp. 1909-1920, 2010.

[4] Q. K. Beg and R. Gupta, "Purification and characterization of an oxidation-stable, thiol-dependent serine alkaline protease from Bacillus mojavensis," Enzyme and Microbial Technology, vol. 32, no. 2, pp. 294-304, 2003.

[5] R. Gupta, Q. Beg, and P. Lorenz, "Bacterial alkaline proteases: molecular approaches and industrial applications," Applied Microbiology and Biotechnology, vol. 59, no. 1, pp. 15-32, 2002.

[6] M. B. Rao, A. M. Tanksale, M. S. Ghatge, and V. V. Deshpande, "Molecular and biotechnological aspects of microbial proteases," Microbiology and Molecular Biology Reviews, vol. 62, no. 3, pp. 597-635, 1998.

[7] I. N. S. Dozie, C. N. Okeke, and N. C. Unaeze, "A thermostable, alkaline-active, keratinolytic proteinase from Chrysosporium keratinophilum," World Journal of Microbiology and Biotechnology, vol. 10, no. 5, pp. 563-567, 1994.
[8] O. H. Lowry, N. J. Roserbrough, A. L. Farr, and R. J. Randall, "Protein measurement with the Folin phenol reagent," The Journal of Biological Chemistry, vol. 193, no. 1, pp. 265-275, 1951.

[9] U. K. Laemmli, "Cleavage of structural proteins during the assembly of the head of bacteriophage T4," Nature, vol. 227, no. 5259, pp. 680-685, 1970.

[10] P. Bressollier, F. Letourneau, M. Urdaci, and B. Verneuil, "Purification and characterization of a keratinolytic serine proteinase from Streptomyces albidoflavus," Applied and Environmental Microbiology, vol. 65, no. 6, pp. 2570-2576, 1999.

[11] G.-W. Nam, D.-W. Lee, H.-S. Lee et al., "Native-feather degradation by Fervidobacterium islandicum AW-1, a newly isolated keratinase-producing thermophilic anaerobe," Archives of Microbiology, vol. 178, no. 6, pp. 538-547, 2002.

[12] P. Pillai and G. Archana, "Hide depilation and feather disintegration studies with keratinolytic serine protease from a novel Bacillus subtilis isolate," Applied Microbiology and Biotechnology, vol. 78, no. 4, pp. 643-650, 2008.

[13] N. Fakhfakh-Zouari, N. Hmidet, A. Haddar, S. Kanoun, and M. Nasri, "A novel serine metallokeratinase from a newly isolated Bacillus pumilus A1 grown on chicken feather meal: biochemical and molecular characterization," Applied Biochemistry and Biotechnology, vol. 162, no. 2, pp. 329-344, 2010.

[14] A. G. Kumar, S. Swarnalatha, S. Gayathri, N. Nagesh, and G. Sekaran, "Characterization of an alkaline active-thiol forming extracellular serine keratinase by the newly isolated Bacillus pumilus," Journal of Applied Microbiology, vol. 104, no. 2, pp. 411-419, 2008.

[15] X. Lin, J. C. H. Shih, and H. E. Swaisgood, "Hydrolysis of feather keratin by immobilized keratinase," Applied and Environmental Microbiology, vol. 62, no. 11, pp. 4273-4275, 1996.

[16] R. Konwarh, N. Karak, S. K. Rai, and A. K. Mukherjee, "Polymer-assisted iron oxide magnetic nanoparticle immobilized keratinase," Nanotechnology, vol. 20, no. 22, Article ID 225107, 3 pages, 2009. 

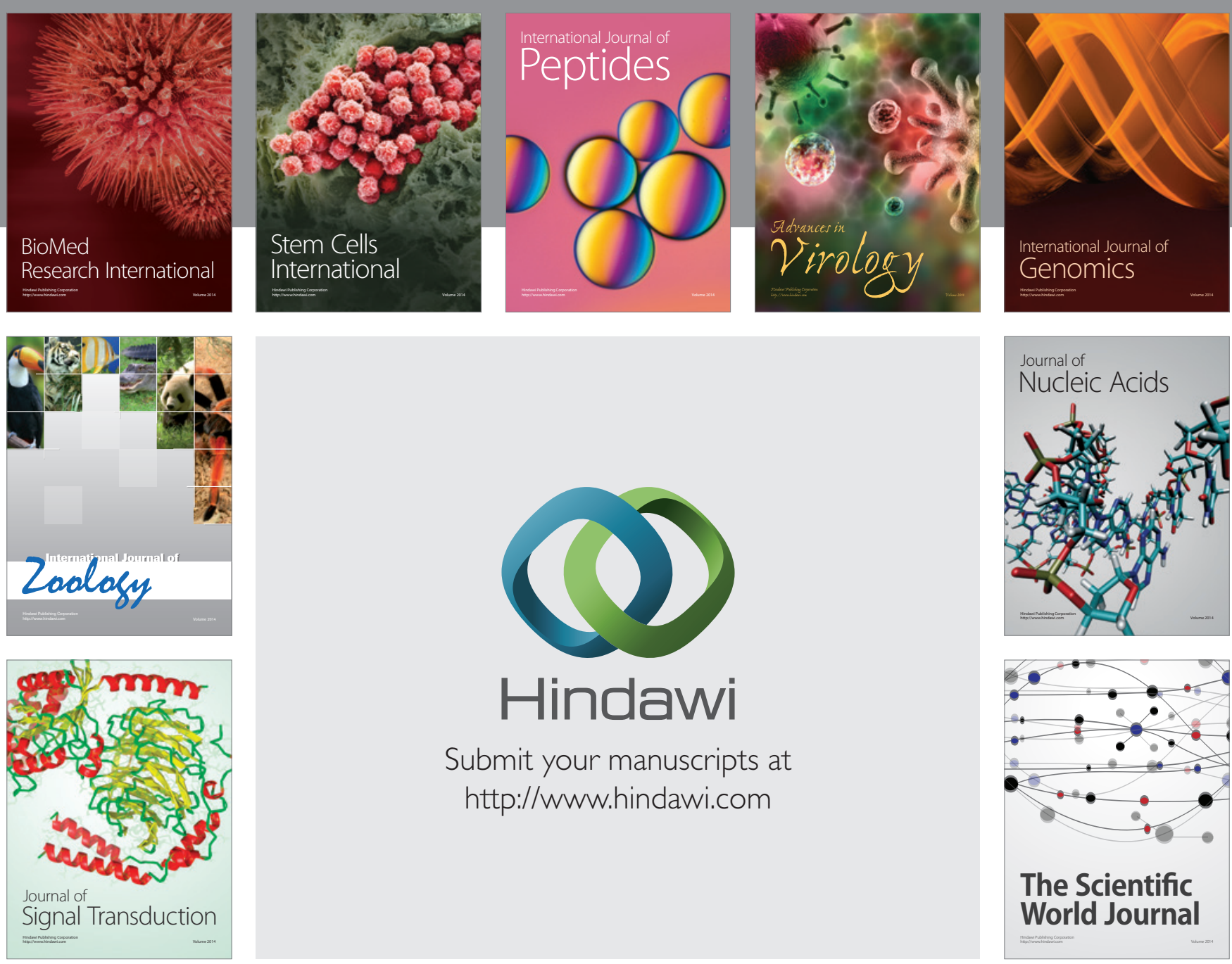

Submit your manuscripts at

http://www.hindawi.com
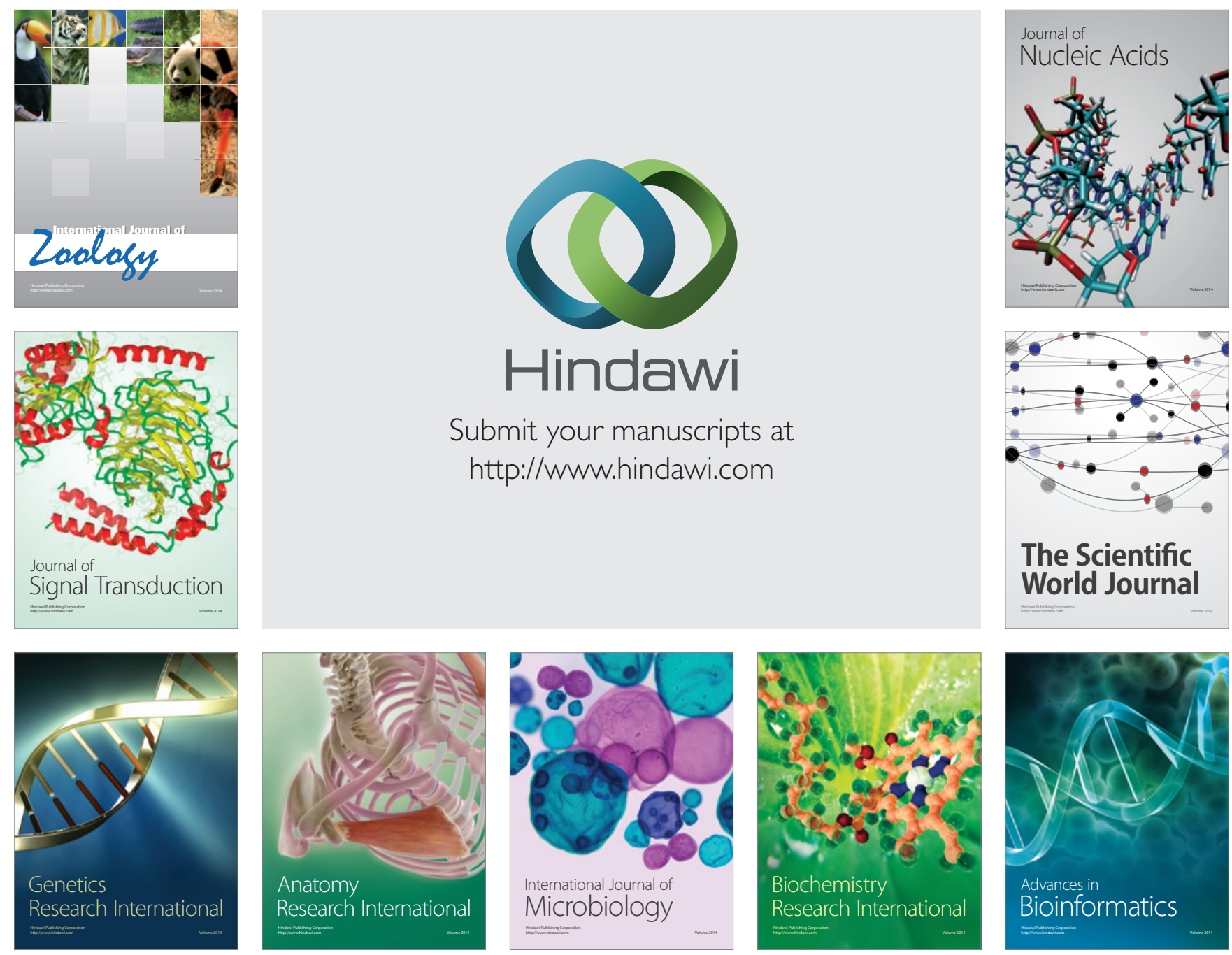

The Scientific World Journal
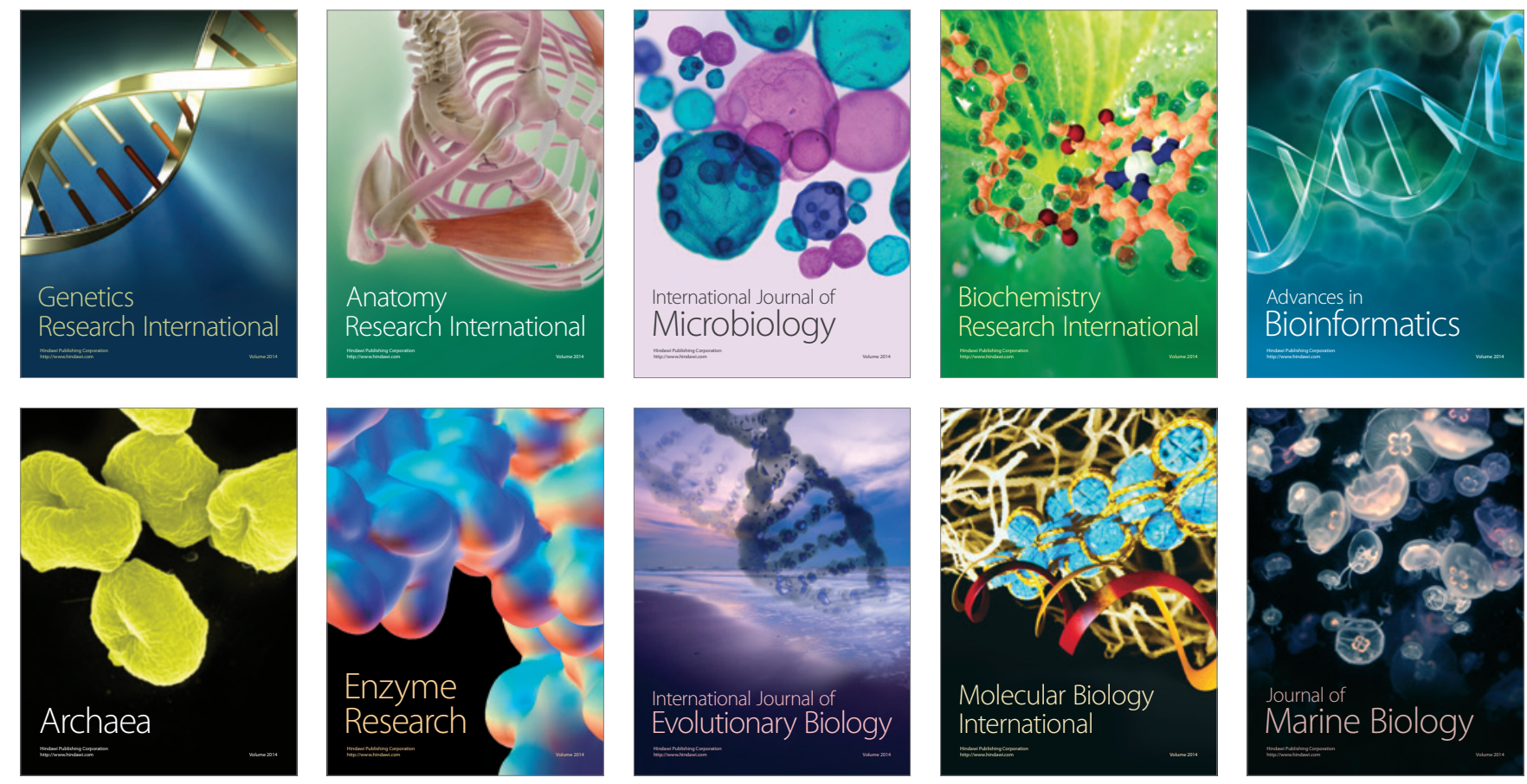